\title{
Dye pH variation on blueberry anthocyanin based dye sensitized solar cell
}

\author{
Zainul Abidin, Eka Maulana, Panca Mudjirahardjo, M. Ivan Fadillah \\ Department of Electrical Engineering, Universitas Brawijay a, Indonesia
}

\begin{tabular}{|c|c|}
\hline Article Info & ABSTRACT \\
\hline Article history: & \multirow{8}{*}{$\begin{array}{l}\text { Anthocy anin is a type of natural pigment that gives color to plants and can be } \\
\text { used to absorb visible light with wavelength of } 400-600 \mathrm{~nm} \text {. The absorption } \\
\text { ability is very useful for dye in designing dye sensitized solar cell (DSSC). } \\
\text { The anthocy anin can be extracted from blueberry and has unique characteristic } \\
\text { of high stability when it reaches low pH. In this paper, design of DSSC with } \\
\text { dye made of blueberry anthocy anin and its performance related to pH variation } \\
\text { is presented. The performance was evaluated experimentally according to } \\
\text { output voltage and current generated by } 4 \text { fabricated samples (pH of } 1.5,2 \text {, } \\
2.6,4.4 \text { ) from A.M } 1.5 \text { sunlight and } 10 \text {-watt LED. Experiment results show } \\
\text { that for both light sources, dye with pH of } 1.5 \text { has the highest output voltage } \\
\text { and current among the others. Since the output voltage and current are very } \\
\text { small, the exsisting design of DSSC is suitable to be developed for optical } \\
\text { sensor. }\end{array}$} \\
\hline Received Jul 28, 2019 & \\
\hline Revised Oct 30, 2019 & \\
\hline Accepted Feb 22, 2020 & \\
\hline Keywords: & \\
\hline Blueberry anthocyanin & \\
\hline Dye & \\
\hline $\begin{array}{l}\text { Dye sensitized solar cell } \\
\mathrm{pH} \text { variation }\end{array}$ & \\
\hline
\end{tabular}

This is an open access article under the $\underline{C C B Y-S A}$ license.

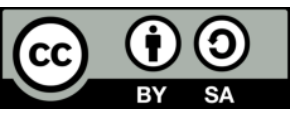

\section{Corresponding Author:}

Zainul Abidin,

Department of Electrical Engineering,

Universitas Brawijaya,

Jl. MT Haryono 167 Malang, Indonesia.

Email: zainulabidin@ub.ac.id

\section{INTRODUCTION}

The world is depending energy source mainly from non renewable sources, such as fossil fuel and coal, which time by time is being decreasing [1-4]. Therefore, the world is now looking for solution from renewable energy sources like water, solar, wind, and tidal to provide the consumers demand [5]. Among the mentioned renewable energies, solar energy is the most favorable energy source, because it is clean, unlimited sources and can be used everywhere on the world [6,7]. Solar energy is converted into electrical energy through a process called photovoltaic effect $[8,9]$.

Dye Sensitized Solar Cell (DSSC) is third generation solar cell discovered on 1991 by O'Regan and Gratzel, after monocrystalline, polycrystalline and thin film silicon [10]. After that, the DSSC has been attracted many researchers to be developed [11, 12]. The DSSC was basically imitated the process of photosynthesis to catch the solar energy (photon) and convert the photon into electrical energy [13, 14]. Electrical performance of the DSSC is usually evaluated based on some parameters such as short circuit current (Isc) and open circuit voltage (Voc) $[15,16]$. The DSSC is fabricated by sandwiching semiconductor electrode, dye, electrolyte, and counter electrode. Among all of the parts, dye performs most important role in absorbing and converting light to electrical energy [17, 18]. Therefore, the DSSC performance is highly depends on the dye used as sensitizer [19].

Since ruthenium-based dye usually used for the DSSC is expensive [20], anthocyanin dye can be an option to substitute with low price but without same efficiency. Anthocyanin can be extracted from red cabbage, strawberry, and blueberry [21, 22]. In addition, anthocyanin pigments consist of many kinds 
of dyes; cyanidin, delphinidin, peonidin, malvidin, etc. In particular, it is well known that 15 anthocyanin pigments are contained by the blueberry.

Anthocyanin has a uniqueness structure change at a certain $\mathrm{pH}$. The structure of anthocyanin is not only affecting to stability but also color of the anthocyanin. When conditions are very acidic, i.e. 1-4, anthocyanin will become more stable and red. While at a more alkaline $\mathrm{pH}$, anthocyanin will be yellow, blue or colorless. Changing structural conditions affect the ability of dye in the process of sunlight absorption [23]. The difference in absorbed photons affects the number of electrons excited in dye. This situation makes difference output produced by the designed DSSC. Therefore, in this paper, design of DSSC with blueberry anthocyanin dye is presented and evaluated experimentally according to the effect of dye $\mathrm{pH}$ variation on the output voltage and current.

\section{RESEARCH METHOD}

The DSSC is designed and fabricated through several processes. Basic required materials are transparent conductive oxide (TCO) glass, $\mathrm{TiO}_{2}$, Dye, and electrolite. All materials are arranged like sandwich structure. The detail DSSC fabrication is explained as follows:

\subsection{Design of active area of TCO glass}

TCO glass used in this research is designed as shown in Figure 1. The TCO glass has area of 2.5 x 2.5 $\mathrm{cm}$, but the $2 \times 2 \mathrm{~cm}$ area is used as active area. That is because of reqirement of cable placement for testing or connecting to load.

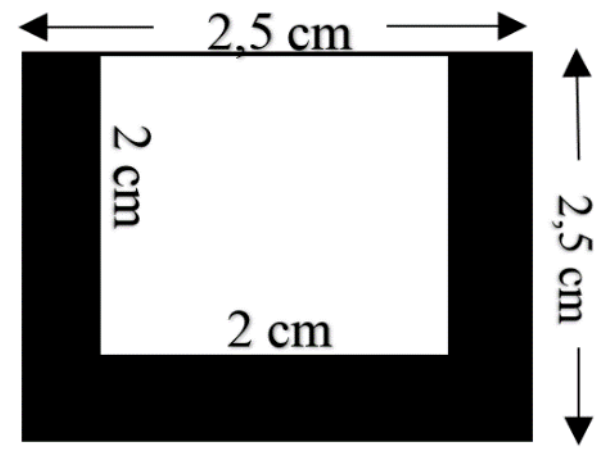

Figure 1. Active area of TCO glass

\subsection{Creating $\mathrm{TiO}_{2}$ paste}

For photoanode, $\mathrm{TiO}_{2}$ is the most suitable semiconductor material. The $\mathrm{TiO}_{2}$ has wide band gap until 3.2eV, nontoxic material, and low cost [24]. The $\mathrm{TiO}_{2}$ paste is created using $\mathrm{TiO}_{2}$ and other materials like Polyvinyl Alcohol (PVA) and aquades. $\mathrm{TiO}_{2}$ powder is needed as much as 0.5 grams while the PVA is more than 1.5 grams because the PVA becomes a substance that makes the mixture has higher thickness. The aquades used in mixing is $13.5 \mathrm{ml}$. All materials are stired up using magnetic stirrer in $45^{\circ} \mathrm{C}$ to obtain solution thick and homogeneous. Aluminum foil is needed to cover the beaker glass so that the distilled water does not evaporate.

\subsection{Creating anthocyanin dye from blueberry}

Blueberries are extracted to get anthocyanin for dye of DSSC. Four anthocyanin dye samples are made with variety of acetic acid solvents for realizing four different dye $\mathrm{pH}$ (see Figure 2 (a)). The dye $\mathrm{pH}$ indicates hydrogen ion concentration for helping electron flow in anthocyanin. So that, the lower dye $\mathrm{pH}$ the higher output of the DSSC. Figures 2 (a) and (b) show dye soaking for 24 hours and filtering, respectively, which are needed to make the dye ready to use.

\subsection{Spin coating deposition}

Spin coating method is chosen for deposition process to make $\mathrm{TiO}_{2}$ paste is coated the TCO. As illustrated in Figure 3 [25], the process begins with penetrating the $\mathrm{TiO}_{2}$ paste and then is carried out by rotation for around $500 \mathrm{rpm}$. In order to get a thin layer, rotation must be accelerated to $1000-1500 \mathrm{rpm}$. When the substrate at constant high speed, homogeneous layer thickness will be obtained. 


\subsection{Firing $\mathrm{TiO}_{2}$ paste and soaking $\mathrm{TiO}_{2}$ paste into dye}

Firing process of $\mathrm{TiO}_{2}$ paste using electric furnace with temperature of $250^{\circ} \mathrm{C}$ takes 20 minutes. The firing process is important to make perfect attachment between $\mathrm{TiO}_{2}$ and $\mathrm{TCO}$ glass. After that, the TCO glass is soaked in dye solution for 10 minutes.

\subsection{Carbonization of counter electrode and giving electrolyte solution}

In this DSSC fabrication, carbonization process is done by heating the conductive side of TCO glass on a candle flame during 1 minute until the conductive side of TCO glass is covered by carbon. Electrolyte solution is given to the $\mathrm{TiO}_{2}$ by dripping the electrolyte using pipette approximately $0.25 \mathrm{ml}$. The electrolyte is used for medium of electron transport from carbon to the dye.

Finally, the DSSC is finalized by uniting the anode ( $\mathrm{TCO}$ glass coated with $\mathrm{TiO}_{2}$, Dye and electrolyte) with the cathode (TCO glass used as a counter electrode) which is arranged face to face and put together with a paper clip to avoid shifting. The fabricated DSSCs are differentiated by sample $1(\mathrm{pH}=1.5)$, sample $2(\mathrm{pH}=2)$, sample $3(\mathrm{pH}=2.6)$, and sample $4(\mathrm{pH}=4.4)$ which can be seen in Figure 4.

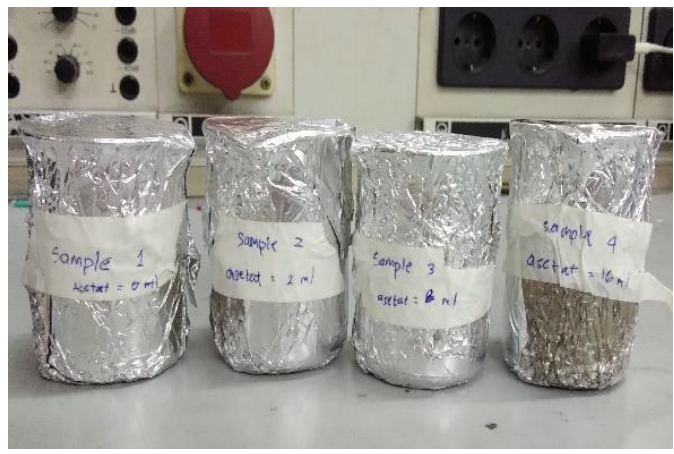

(a)

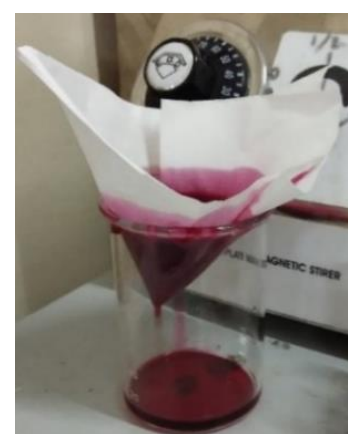

(b)

Figure 2. (a) Dye soaking with different amount of acetic acids, (b) Dye filtering
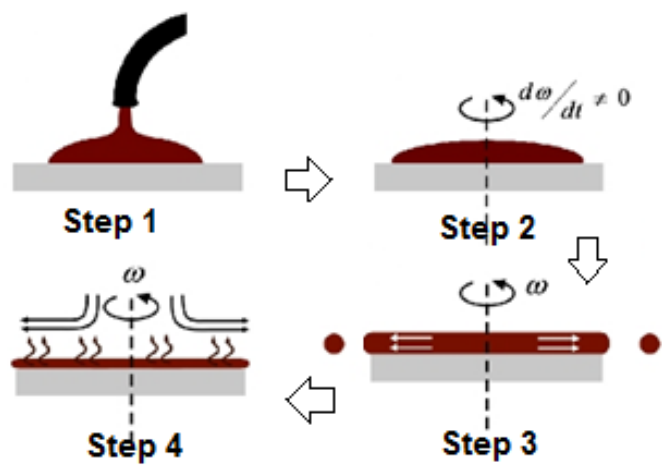

Figure 3. Spin coating process

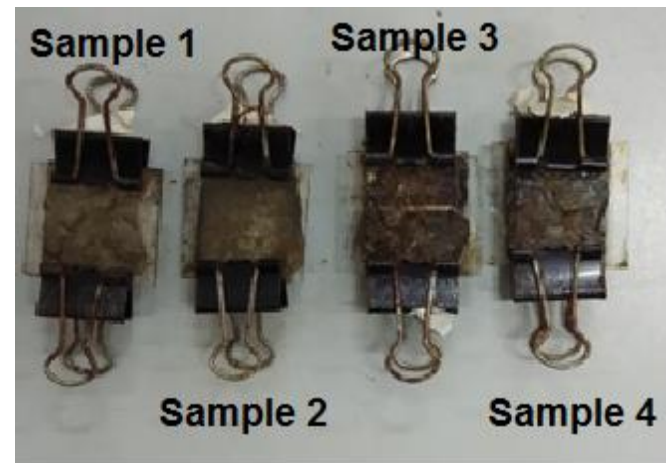

Figure 4. Fabricated DSSCs

\section{RESULTS AND ANALYSIS}

In this section, experimental results are presented and discussed. The experiments are related to dye absorbance, output voltage and current with light sources of AM 1.5 sunlight and 10 watt LED. The detail discussions about the experiments are as follow.

\subsection{Dye absorbance experiment}

Dye absorbance is important to be tested to confirm the amount of visible light can be absorbed and its working wavelenght. Previous research mentioned that maximum anthocyanin absorbance throughout the visible spectrum is in $510 \mathrm{~nm}$ [26]. In this research, spectrophotometer UV-1800 was used to confirm the dye absorbance. Since the used spectrophotometerhas maximum measurement of $4 \AA$, dilution uses ratio 
of 1: 5 for dye: solvent must be done first so that the absorbance of the dye does not exceed the maximum limit. Variation of dye absorbance related to $\mathrm{pH}$ is illustrated in Figure 5. All samples work at the wavelenght range of 400-600 $\mathrm{nm}$. Sample 1 has maximum absorbance $(4 \AA)$ as the same as sample 2 . However, sample 1 has wavelenght range of 516-535 $\mathrm{nm}$ which is wider than of sample $2(521-535 \mathrm{~nm})$. Samples 3 and 4 have maximum absorbance of $3 \AA$ and $0.32 \AA$ with wavelenght range of 528-535 nm and 517-539 nm, respectively. Finally, among 4 samples, the sample with smallest $\mathrm{pH}$ (1.5) has the best performance of visible light absorption.

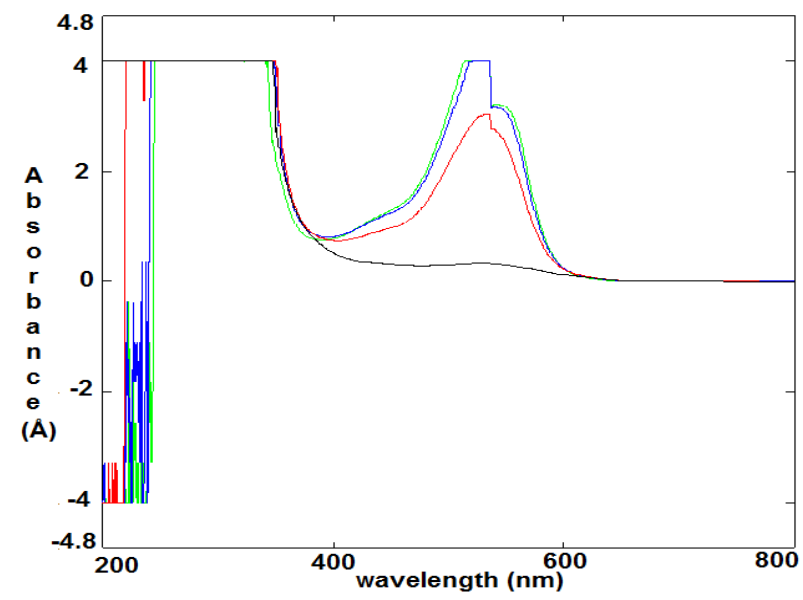

Figure 5. Dye absorbance based on different pHs

\subsection{DSSC experiment with AM 1.5 sunlight}

The fabricated DSSCs were tested with AM 1.5 sunlight to get output of open circuit voltage (Voc) and short circuit current (Isc). Based on observation, the AM 1.5 sunlight can be obtained at 8.15am, because at that time, shadow length (13.005) and object length $(8 \mathrm{~cm})$ fulfill the formula given in (1). The results are summarized in Table 1. It can be confirmed that sample 1 with the most acidic $\mathrm{pH}$ has the highest Voc $(506 \mathrm{mV})$ and Isc $(4 \mu \mathrm{A})$. While smallest $\operatorname{Voc}(378 \mathrm{mV})$ and Isc $(3.3 \mu \mathrm{A})$ were generated by sample 4 . Therefore, sample 1 has the best performance among the other 4 samples. The lower $\mathrm{pH}$ of the dye, the higher Voc and Isc will be produced the fabricated DSSC. However, in this research, $1.5 \mathrm{pH}$ cannot be confirmed as the maximum performance, the one with lower that 1.5 may has maximum performance.

$$
A M 1,5=\sqrt{1+\frac{s}{o}}
$$

where; s=shadow length

$\mathrm{o}=$ object length

Table 1. Experiment results with AM 1.5 sunlight

\begin{tabular}{lcc}
\hline \multicolumn{1}{c}{ Sample } & Voc $(\mathrm{mV})$ & Isc $(\mu \mathrm{A})$ \\
\hline $1(\mathrm{pH}=1.5)$ & 506 & 4 \\
$2(\mathrm{pH}=2)$ & 468 & 3.7 \\
$3(\mathrm{pH}=2.6)$ & 433 & 3.7 \\
$4(\mathrm{pH}=4.4)$ & 378 & 3.3 \\
\hline
\end{tabular}

\subsection{DSSC experiment with 10 watt LED}

Second output experiment of DSSC is using coolday light 10 watt LED that makes temperature is between $25 \cdot 6^{0}-26.3^{\circ} \mathrm{C}$. So that the temperature does not affect too much to output of DSSC. The experiment of DSSCs carried out with variations in light illuminance ranging from $3200 \mathrm{Lux}-5300 \mathrm{Lux}$. All samples will be measured with each light variant with a difference of $300 \mathrm{Lux}$ for each experiment.

Based on Figure 6, there are no significant differences between sample $1(\mathrm{pH}=1.5)$ and sample 2 $(\mathrm{pH}=2)$ and between sample $3(\mathrm{pH}=2.6)$ and sample $4(\mathrm{pH}=4.4)$. However, there is a considerable difference 
between sample 2 and sample 3. It can also be seen that s ample 1 has the largest output voltage with an average of $457.6 \mathrm{mV}$.

By using the same method (difference of 300 Lux), the current measurement was carried out on 4 samples with 10 Watt LED lights. The experimental results are shown in Figure 7 . It can be seen that as the same as output voltage, sample 1 has the higher average output current, which is $2.3 \mu \mathrm{A}$. However, unlike the output voltage, the output current difference is quite significant between sample $3(\mathrm{pH}=2.6)$ with sample $4(\mathrm{pH}=4.4)$ while for sample 1 , sample 2 , and sample 3 , there is no significant difference in the output current.

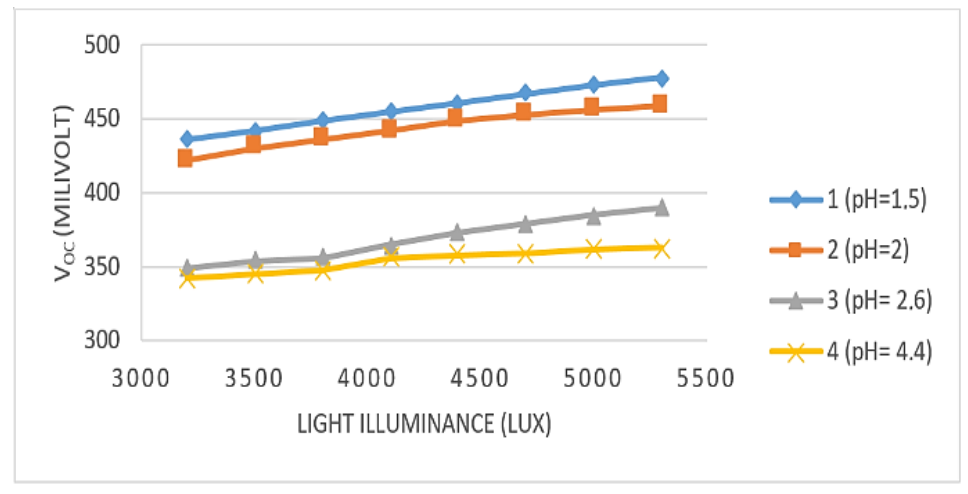

Figure 6. Voc of the DSSCs with 10 watt LED

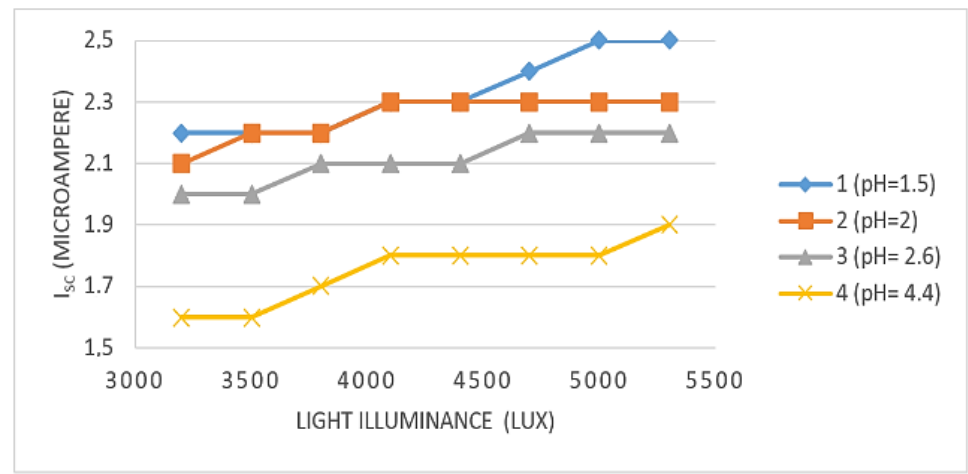

Figure 7. Isc of the DSSCs with 10 watt LED

\section{CONCLUSION}

In this paper, DSSCs with dye based on blueberry anthocyanin have been fabricated and evaluated experimentally according to dye $\mathrm{pH}$ variation effect. The experiment results of 4 DSSCs with different dye $\mathrm{pH}$ show that higher dye $\mathrm{pH}$ has lower light absorbance and lower dye $\mathrm{pH}$ (close to 1) produces higher light absorbance. Moreover, according to the output, the DSSC with dye pH of 1.5 (the most acidic) has the highest output voltage and current among the others. Since the output voltage and current are in the order of $\mathrm{mV}$ and $\mu \mathrm{A}$, suitable further development of the DSSC is for optical sensor. Furthermore, performance of dye $\mathrm{pH}$ lower than 1.5 is not confirmed. Maxmimum absorbance of the blueberry anthocyanin based dye may not be at $1.5 \mathrm{pH}$. Therefore, in the future, dye $\mathrm{pHs}$ lower than 1.5 will be tested to confirm the minimum $\mathrm{pH}$ that can make dye works at the maximum absorbance.

\section{REFERENCES}

[1] S. Sharma, et al., "Solar Cells: In Research and Applications-A Review," Materials Sciences and Applications, vol. 6, no. 12, pp. 1145-1155, 2015.

[2] Frankfurt School-UNEP, "Global Trends in Renewable Energy Investment 2016," 2016. [Online]. Available: http://fs-unep-centre.org/fileadmin/gtr/Global_Trends_Report_2016.pdf 
[3] World Energy Council, "World Energy Resources," 2016. [Online]. Available: https://www.worldenergy .org/publications/entry/world-energy-resources-2016

[4] International Energy Agency, "Key World Energy Statistics," 2016. [Online]. Available: https://www.iea.org/reports/key-world-energy-statistics-2019

[5] S. Sanaeepur, et al., "Renewable Energies: Climate-change Mitigation and International Climate Policy," International Journal of Sustainable Energy, vol. 33, no. 1, pp. 203-212, 2014.

[6] E. Zakhidov, et al., "Energy Efficiency of the Sunlight Harvesting and Storing Sy stem in Bacterial Photosynthesis," Turkish Journal of Biology, vol. 39, pp. 276-283, 2015.

[7] J. Rogers. and L. Wisland, "Solar Power on the Rise: The Technologies and Policies behind a Booming Energy Sector," Union of Concerned Scientists, 2014.

[8] L.C. Chen, et al., "Fabrication and Properties of High-Efficiency Perovskite/PCBM Organic Solar Cells," Nanoscale Research Letter, vol. 10, no. 312, pp. 1-5, 2015.

[9] Z. Abdin, et al., "Solar Energy Harvesting with The Application of Nanotechnology," Renewable and Sustainable Energy Reviews, vol. 26, pp. 837-852, 2013.

[10] B. O'Regan and M. Grätzel, "A low-cost, high-efficiency solar cell based on dye-sensitized colloidal $\mathrm{TiO}_{2}$ films," Nature, vol. 353, pp.737-740, 1991.

[11] K. Park, et al., "Enhanced Charge Transport Properties By Strengthened Necks Between $\mathrm{TiO}_{2}$ Aggregates For Dye Sensitized Solar Cells," Thin Solid Films. vol. 588, pp. 19-25, 2015.

[12] S. Sharma, et al., "Dye Sensitized Solar Cells: From Genesis to Recent Drifts," Renewable Sustainable Energy Reviews, vol. 70, pp. 529-537, 2017.

[13] C.C.V. Pablo, et al., "Construction of Dye-sensitized Solar Cells (DSSC) with Natural Pigments," in Materials Today Proc., vol. 3, no. 2, pp. 194-200, 2016.

[14] X. Guo, et al., "Graphene-Based Materials for Photoanodes in Dye-Sensitized Solar Cells," Front. Energy Res., vol. 3, pp. 1-5, 2015.

[15] Rahmadwati, et al., "Optical Sensor Based on Dye-Sensitized Solar Cell (DSSC)," Indonesian Journal of Electrical Engineering and Computer Science (IJEECS), vol. 12, no. 2, pp.685-690, 2018.

[16] E. Maulana, et al., "Optical Sensor Based on Dye-Sensitized Solar Cell (DSSC) with Tobacco Chlorophyll," TELKOMNIKA Telecommunication Computing Electronics and Control, vol. 17, no. 4, pp. 1907-1913, 2019.

[17] E. Jonathan, et al., "Natural Pigments as Sensitizers for Dye Sensitized Solar Cells," Advances in Materials, vol. 5, no. 5, pp. 31-34, 2016.

[18] A. Oluwaseun, et al., "Review on Natural Dye-Sensitized Solar Cells Review on Natural Dye-Sensitized Solar Cells (DSSCs)," International Journal of Engineering Technologies, vol. 2, no. 2, pp. 34-41, 2016.

[19] I.S. Mohamad, et al., "ZnO Photoanode Effect on the Efficiency Performance of Organic Based Dye Sensitized Solar Cell," IOP Conference Series: Materials Science and Engineering, 2017.

[20] N. Sawhney, et al., "Utilization of Naturally Occurring Dyes as Sensitizers in Dye Sensitized Solar Cells," IEEE Journal of Photovoltaics, vol. 7, no. 2, pp. 539-544, 2017.

[21] A. Mizuno, et al., "Natural Dye-Sensitized Solar Cells Containing Anthocyanin Dyes Extracted From Frozen Blueberry Using Column Chromatography Method," in 2018 IEEE 7th World Conference on Photovoltaic Energy Conversion (WCPEC), Waikoloa Village, 2018.

[22] D. Isoda, et al., "Dye Sensitized Solar Cells Containing Anthocy anin Dyes Extracted From Frozen Red Cabbages," in 1st International Caparica Conference on Chromogenic and Emissive Materials (IC3EM). Lisbon, 2014.

[23] M. Andersen and K.R. Markham, "Flavonoid: Chemistry, Biochemistry, and Applications," New York: Taylor \& Francis Group, 2006.

[24] P. Bhambhani, "Quantum Dot-sensitized Solar Cells: A Review," Bulletin of Electrical Engineering and Informatics, vol. 7, no.1, pp. 42-54, 2018.

[25] Hellstrom S. L., "Basic Models of Spin Coating. Coursework for physics 210," California: Stanford University, 2007.

[26] E. W. Ronald, "Color and Pigment Analyses in Fruit Products," Oregon: Oregon State University, 1993. 